Bicameral Mind. The brain is apparently split into a left half which is the home of rationalist, logical and scientific thought and a right half which houses artistic feelings and intuitive insights. Human development has led to a changeover in the dominant section. Civilization has suppressed the messages from the right brain and allowed the left brain to take over.

The second section of the book deals with the life histories and scientific achievement of some of the great renaissance scientists, Copernicus, Brahe, Kepler, Galileo, Newton and Hershel. The ghosts of Koestler's The Sleepwalkers and Dreyer's A History of Astronomy from Thales to Kepler haunt these pages.

The third section brings us firmly to the present day and traces the acceleration of astronomical discovery that has occurred since Einstein's gravitational theory and the advent of quantum mechanics. Planetary exploration, radio astronomy, big bang cosmology, black holes, the origin of life - all are touched upon. Throughout the text echoes the Wilson message that there is more to our astronomical Universe than science can understand. The investigators must try and tune into this ethereal suprahuman influence on our destiny in a manner similar to that used by our ancient ancestors.

I enjoyed reading this book. It was fun. The style is excellent, the production standard and the illustrations are superb. But I continually had an uneasy feeling. It is an axiom that you should not believe all that you read; the reader of this book should not, and Colin Wilson should not either. $\mathrm{He}$ has a regrettable tendency to regard the printed word in the same light as the tablets of Moses. Many eminent authors are quoted - Hoyle, Koestler, Motz, Taylor. When discussing Hoyle's Lifecloud and Ten Faces of the Universe, Wilson states that "No-one is going to quarrel with what they say". What? Scientists always question what other people say. The scientists such as Galileo, Kepler and Newton who are discussed in Wilson's book thrived on it. So should the readers of Starseekers.

But still, I congratulate Colin Wilson. Once you pick the book up it is hard to put it down. Interesting thoughts and problems sparkle from every other page.

David W. Hughes is a Lecturer in Astronomy and Physics at the University of Sheffield.

\title{
James Six and his thermometer
}

\section{W. D. Hackmann}

The Construction and Use of a Thermometer. By James Six. Introduction by Jill Austin and Anita McConnell. Pp.123. (Nimbus: London, 1980.) £15.

THIS small book reproduces the papers of an almost totally forgotten eighteenth century man of science, James Six (1731 1793), the descendant of a refugee Walloon family of silk weavers who settled in Canterbury during the reign of Elizabeth I. He was one of a score of amateur scientists who, through their individual small contributions, made scientific progress possible during the eighteenth century.

His tastes were typical of the contemporary intelligensia; painting, astronomy, electrical experiments with the new-fangled frictional electric machines, and meteorological observations. $\mathrm{He}$ invented a maximum and minimum selfregistering thermometer in 1780; a worthwhile contribution for which he was awarded a Royal Society Fellowship in 1792. His thermometer, in which the extremes of temperature were recorded by sliding indexes, has survived as a popular domestic instrument. With it he observed the night-time inversion of temperature, a phenomenon not explained by meteorologists until the following century.

The largest portion of the book is taken up with a reproduction of Six's Construction and Use of a Thermometer, published in 1794 , and essentially a summary of his three papers on thermometry published in the Philosophical Transactions with the addition of a chapter on the deep-sea use of his instrument. Eight pages are devoted to his other scientific communications. The bulk of these are his seven letters to the Gentleman's Magazine, a popular organ for the amateur scientist. In 1770 he described a comet later known as Lexell's Comet. Its orbit was calculated by the American astronomer David Rittenhouse and Six's observations largely agreed with this. In 1771 and 1781 he recorded the appearance of two other comets. Other topics dealt with were the 1784 heat wave, William Herschel's recently discovered "Georgian Star"' (Uranus) and a severe frosty spell in 1789. Also reproduced is a letter from the archives of the Cambridge University Library, written in 1785 by Six to a student friend of his son on the use of his thermometer. This series is terminated by a charming obituary of Six, also from the Gentleman's Magazine.

The only Six-type thermometer known before the researches of Austin and McConnell was the one in the Museum of the History of Science at Oxford. However, it is not contemporary, having probably been made in the 1820 s for Charles Daubeny whose chemistry laboratory was housed in the present basement of this Museum. The authors have identified 26 thermometers made by Six and now part of the King George III Collection at the Science Museum in London, and another specimen of obscure origin at the Copernicus Museum in Rome. These are described in some detail and the subsequent development of the instrument is also given.

All in all, this small, attractively-bound volume not only adds a little to the history of thermometry, it also gives us another glimpse into the world of eighteenthcentury men of science.

W. D. Hackmann is Assistant Curator of the Museum of the History of Science, University of Oxford. 